\title{
In-vitro Sensitivity of Selected Enteric Bacteria to Extracts of Allium sativum L.
}

\author{
Musa O. AREKEMASE, David O. ADETITUN, Ganiyu P. OYEYIOLA \\ University of Ilorin, Faculty of Science, Department of Microbiology, P.M.B 1515, Ilorin, Kwara \\ State, Nigeria; arekemase.om@unilorin.edu.ng ( ${ }^{*}$ corresponding author)
}

\begin{abstract}
Garlic has been used throughout all of recorded history for culinary and medicinal reasons. The portion of the plant most often consumed is an underground storage structure called a head. The antimicrobial effects of Allium sativum (garlic) against some bacterial isolates were investigated using the agar diffusion well method. Standard methods were used to carry out the investigation. Photochemical analyses of the ethanolic extracts showed the presence of many secondary metabolites such as saponins, tannins, alkaloid steroids and glycosides. The minimum inhibitory concentration and minimum bactericidal concentration of the agent (garlic) was determined for both the aqueous and ethanolic extract. The ethanolic extract was more effective than the aqueous extract, inhibiting all the test organisms. While the aqueous extracts was effective against Escherichia coli, Pseudomonas aeruginosa and Klebsiella pneumoniae. Garlic extracts are strictly broad-spectrum with immune boosting phytonutrients from Allium 'family.' Further research will need to be done to carry out the purification of the active ingredients which have potential for combating human disease. Also, toxicological studies need to be evaluated.
\end{abstract}

Keywords: extract, in vitro, garlic, phytonutrient, test organism

\section{Introduction}

Garlic belongs to the family Alliaceae and its scientific name is Allium sativum. Other members of the family are leek, onion, and shallot. Garlic is popularly used in culinary and medicine (Karuppiah and Rajaram, 2012). Herbs and spices are very essential and indispensable as therapeutic agents against many pathological infections (Gull et al., 2012). Phytotherapeutic agents such as Allium sativum which are commonly utilized in alternative medicine have gained immense interest in medical literature (Iwalokun et al., 2004). Garlic is present in various forms namely, garlic oil, garlic powder, raw juice and many types of extracts such as, aged garlic extract, aqueous garlic extract (AGE), methanolic extract, ethanolic extract and many more (Jabar and Al-Mossawi, 2007).

The therapeutic effect of garlic is possible because of its oil-water soluble organosulfur compounds, which are responsible for its typical flavor and odour. Thiosulfinates play a major role in the antibiotic activity of garlic (Durairaj et al., 2009). In recent times a number of studies have been conducted to verify the effectiveness of plant extracts against bacterial infections (Prashanth et al., 2006; UngKyu et al., 2010). A daily dose of $1 \mathrm{~mL} / \mathrm{kg}$ body weight of garlic extract for six months can result in significant reduction in oxidant stress in the blood of patients with artherosclerosis and cholesterol circulating in the blood stream. The abilty of garlic to prevent these oxidation reactions may explain some of its useful effects in artherosclerotic heart diseases (Karuppiah and Rajaram, 2012).
The enteric bacteria are members of the family enterobactericeace which is large heterogeneous group of Gram negative rods whose natural habitat is the intestinal tracts of humans and some other animals (Ilori et al., 1996). They are facultative anaerobes that ferment a wide range of carbohydrates, possess a complex antigenic structure produce a variety of toxin and other virulent factors. The family includes members of the genera: Shigella, Escherichia, Salmonella, Proteus, Serratia, Arizona, Enterobacter (Pelczar et al., 1993).

This study seeks to determine in -vitro the minimum inhibitory concentration, minimum bactericidal concentration of some enteric bacteria to extracts of Allium sativum and the dosage at which this is achieved.

\section{Materials and methods}

\section{Collection and treatment of plant materials}

Samples of Allium sativum were used in this study. They were purchased fresh from Ipata market, Ilorin, Nigeria. The samples were then sun dried for two weeks after which they were milled into coarse powder with a Qlink electic blender; the milled samples were kept in tight bottles.

\section{Extraction procedure}

Aqueous and ethanolic extracts of Allium sativum were prepared using the method described by Barry and Thornsberry (1991). 
184

\section{Aqueous extract}

Twelve grams of the blended sample was measured into a conical flask and $100 \mathrm{ml}$ of sterile distilled water was added, covered with a cork, mixed together properly and left in the shaker at 100 revolution per minute for 24 hours. The sample was filtered and squeezed through four layers of muslin cloth. The filtrate was then centrifuged at 2,000 revolutions per minute (r.p.m.) for 5 minutes after which it was decanted. The pellet was discarded and the supernatant was sterilized by using the membrane filtration unit with type HC filters. The filtrate obtained was stored in sterile McCartney bottles and kept in the refrigerator at $4^{\circ} \mathrm{C}$ and later used for antimicrobial tests.

\section{Ethanolic extract}

Twelve grams of the blended sample was measured into a conical flask and $100 \mathrm{ml}$ of $95 \%$ ethanol was added; covered with a cork, mixed together and left on the shaker at 100 r.p.m. for 24 hours after which the extract was filtered and squeezed through four layers of muslin cloth. The filtrate was then centrifuged at 2,000 r.p.m. for 5 minutes after which it was decanted. The pellet was discarded and the supernatant was sterilized by using the membrane filtration unit with type HC filters. The filtrate obtained was stored in sterile McCartney bottles and kept in the refrigerator at $4^{\circ} \mathrm{C}$ and later used for antimicrobial tests.

\section{Sterility test of the plant extract}

Each of the above extract (aqueous extract and ethanolic extract) was tested for growth or contaminant. This was carried out by inoculating $1 \mathrm{ml}$ of each of them on Nutrient agar and incubated at $37^{\circ} \mathrm{C}$ for 24 hours (Barry and Thornsberry, 1991). The plates were observed for growth. Absence of growth in the extracts after incubation indicated that the extracts were sterile. The extracts were then assessed for antimicrobial activity.

\section{Sterilization of materials}

All glassware used were washed with detergent, rinsed properly with tap water and dried. They were then sterilized by wrapping in Aluminium foil in a hot air oven at $160^{\circ} \mathrm{C}$ for 90 minutes. All the media, distilled water, and McCartney bottles used were sterilized in the autoclave at $121^{\circ} \mathrm{C}$ for 15 minutes. The laboratory bench was swabbed with $70 \%$ alcohol before and after each round of experiment.

\section{Collection and maintenance of test organisms}

Pure cultures of bacteria isolated from clinical specimen were obtained from the microbiology and parasitological laboratory of University of Ilorin Teaching Hospital (UITH), Kwara State, Nigeria, and were used in this study. The organisms are Staphylococcus aureus, Escherichia coli, Pseudomonas aeruginosa, Bacillus subtilis and Klebsiella pnemoniae. The organisms were maintained on $\mathrm{Nu}-$ trient agar slants at $4^{\circ} \mathrm{C}$ and were routinely sub-cultured during storage.

\section{Preparation and standardization of bacterial inoculum}

Preparation and standardization of each bacterium inoculum was done using the method described by Odebiyi and Sofowora (1979). This was carried out by picking test organism growing as a pure culture on solid media and then transferred into sterile nutrient broth and incubated for 18-24 hours to produce a growth of the same turbidity. Each standardized inoculum was used for antimicrobial test.

\section{Preparation of culture media}

The materials used for the preparation of culture media were spatula, conical flasks, aluminum foil, Bunsen burner and tripod stand, autoclave, weighing balance, cotton wool, and measuring cylinder. The culture media used in this project work were Nutrient agar, Mueller Hinton agar, and Nutrient broth. All media were prepared according to manufacturers specifications. For example, Nutrient agar powder $(14 \mathrm{~g})$ was dissolved in a sterile conical flask containing $500 \mathrm{ml}$ of sterile distilled water. The suspension was heated to boiling and was autoclaved at $121^{\circ} \mathrm{C}$ for 15 minutes. After autoclaving, the media was allowed to cool to a temperature of about $45^{\circ} \mathrm{C}$ before pouring into Petri dishes

\section{Phytochemical screening of the extract of Allium sativum}

The methods described by Odebiyi and Sofowora (1978) were used to determine the presence of saponins, tannins, phenolics and alkaloids, Lieberman Burchad reaction as described by Harborne (1973) was used to test for Steroids, while the Salkowski test was used to test for the presence of glycosides.

\section{Antibacterial test}

The antibacterial properties of the aqueous and ethanolic extracts were determined using the agar well diffusion method of Bauer et al. (1996). Twenty-four hour old broth cultures of each test organism (standardized inoculum) were swabbed onto sterile Mueller Hinton agar in Petri dishes using sterile cotton swab. A sterile stainless steel cork borer of size $5 \mathrm{~mm}$ in diameter was used to make wells on the plates. The holes were filled with $10 \mathrm{mg} / \mathrm{ml}, 20 \mathrm{mg} /$ $\mathrm{ml}$ and $30 \mathrm{mg} / \mathrm{ml}$ of the extracts. Each well was labeled appropriately. Control experiment was also set up where the holes were filled with sterile distilled water. The sterile distilled water and the extract were incorporated into the holes by the use of sterile $2 \mathrm{ml}$ syringes.

The inoculated Petri dishes were left for an hour at room temperature for the extract to diffuse before the growth of organism commenced. The plates were incubated at $37^{\circ} \mathrm{C}$ for 24 hours after which the result were read by measuring 
the diameters of zones of inhibition around the wells with the aid of a metric ruler and recorded. The antimicrobial studies were done in duplicates and diameters of zones of inhibition $(\mathrm{mm})$ are expressed as means and standard errors on means. A larger zone of inhibition indicated the test substance was very active against the bacteria. A small zone may mean that the substance was only slightly active against the organism, and no zone may mean no activity, but this might also mean that the substance was unable to diffuse through the agar.

\section{Minimum inhibitory concentration (MIC)}

The MIC of ethanolic extract was determined using agar dilution method described by Mitscher $e$ al. (1972) and Baker and Breach (1980). One milliliter of different concentration of each of the extract was added to $14 \mathrm{ml}$ of Nutrient agar to make the final concentration ranging from $10 \mathrm{mg} / \mathrm{ml}$ to $30 \mathrm{mg} / \mathrm{ml}$ of the extract in the agar. Standardized inoculum was streaked in a radial pattern on the agar in Petri dishes containing various concentrations of the extracts. The plates were incubated at $37^{\circ} \mathrm{C}$ for 24 hours. The lowest concentration of each extract inhibiting the growth of test organism was taken as the minimum inhibitory concentration.

\section{Minimum bactericidal concentration $(M B C)$}

Visual observation of growth inhibition on solid medium was used to determine MBC as described by Mitscher et al. (1972). The agar plates of different extracts of different concentrations inoculated with organisms were observed for growth after incubation for 24 hours at $37^{\circ} \mathrm{C}$. The plates that show no visible growths were sub-cultured no fresh Nutrient agar plates by picking inoculum form the line of streaking. The lowest concentration of the extracts that does not yield any growth on the solid medium after the incubation period was taken as the minimum bactericidal concentration.

Comparison of the antimicrobial effectiveness of the ethanolic extracts with those of pure conventional antibiotics.

Three antibiotics, chloramphenicol, ampicillin and co-trimoxazole were used. The antimicrobial activity of $12 \mathrm{mg} / \mathrm{ml}$ concentrations of each of the antibiotics were compared with that of plant extracts at the same concentration since the initial concentration of the extract used was $12 \mathrm{mg} / \mathrm{ml}$. Sterile distilled water was used as diluent for the antibiotics while ethanol was used for the extracts. Antibacterial assay was carried out by agar diffusion technique (Leong and Yang, 1981). Zones of inhibition, which are measures of antibacterial activities, were determined around the well.

\section{Results}

The phytochemical screening of Allium sativum showed the presence of saponins, trace amount of tannins and alkaloids and absence of steroids and glycosides this is presented in Tab. 1.

Tab. 1. Phytochemical screening of ethanolic extracts of Allium sativum

\begin{tabular}{cc}
\hline Phytochemicals & Ethanolic extract of Allium sativum \\
\hline Saponins & + \\
Tannins & \pm \\
Alkaloids & \pm \\
Steroids & - \\
Glycosides & - \\
\hline
\end{tabular}

Key: + = Present, - = Absent, $\pm=$ Trace amount

The aqueous and ethanolic extracts of Allium sativum possess appreciable antibacterial activity against some Gram-negative test bacteria. The aqueous extract was found to exhibit differential activity against Escherichia coli, Pseudomonas aeruginosa and Klebsiella pueumoniae. Two bacteria, Staphylococcus aureus and Bacillus subtilis however showed resistance to the aqueous extract. Ethanolic extract was active in all cases with the most activity against Escherichia coli while Staphylococcus aureus showed least sensitivity. This is presented in Tab. 2 and 3.

The minimum inhibitory concentration (MIC) and concentration minimum bactericidal concentration (MBC) of both aqueous and ethanolic extract of Allium sativum are presented in Tab. 4 and 5. For aqueous extracts E. coli was inhibited at $20 \mathrm{mg} / \mathrm{ml}$ while Pseudomonas aeruginosa and Klebsiella pneumonia was inhibited at $30 \mathrm{mg} / \mathrm{ml}$ but Bacillus subtilis and Staphylococus aureus show no zone of inhibition. The aqueous extracts of $\mathrm{Al}$ lium sativum has no bactericidal effects on Staphylococcus aureus, Bacillus subtilis, Klebsiella pneumoniae, Pseudomonas aeruginosa, and Escherichia coli.

Tab. 2. Antimicrobial activity of the aqueous extract of Allium sativum against some selected microorganisms

\begin{tabular}{|c|c|c|c|c|}
\hline \multirow{2}{*}{ Organisms } & \multicolumn{4}{|c|}{ Zone of inhibition $(\mathrm{mm})$ Concentration } \\
\hline & Control & $10 \mathrm{mg} / \mathrm{ml}$ & $20 \mathrm{mg} / \mathrm{ml}$ & $30 \mathrm{mg} / \mathrm{ml}$ \\
\hline Staphylococcus aureus & $0.00 \pm 0.00^{\mathrm{a}}$ & $0.00 \pm 0.00^{\mathrm{a}}$ & $0.00 \pm 0.00^{\mathrm{a}}$ & $0.00 \pm 0.00^{\mathrm{a}}$ \\
\hline Klebsiella pneumoniae & $0.00 \pm 0.00^{\mathrm{a}}$ & $2.50 \pm 0.12^{b}$ & $4.50 \pm 0.21^{c}$ & $6.00 \pm 0.21^{d}$ \\
\hline Escherichia coli & $0.00 \pm 0.00^{\mathrm{a}}$ & $3.00 \pm 0.20^{\mathrm{b}}$ & $7.00 \pm 0.20^{c}$ & $9.50 \pm 0.40^{\mathrm{d}}$ \\
\hline Bacillus subtilis & $0.00 \pm 0.00^{\mathrm{a}}$ & $0.00 \pm 0.00^{\mathrm{a}}$ & $0.00 \pm 0.00^{\mathrm{a}}$ & $0.00 \pm 0.00^{\mathrm{a}}$ \\
\hline Pseudomonas aeruginosa & $0.00 \pm 0.00^{\mathrm{a}}$ & $2.50 \pm 0.10^{\mathrm{b}}$ & $5.00 \pm 0.27^{c}$ & $7.00 \pm 0.21^{\mathrm{d}}$ \\
\hline
\end{tabular}

Key: Each value is a mean of three determinations \pm standard deviation. Different superscripts across the table are significantly different $(p<0.05)$ 
Tab. 3. Antimicrobial activity of ethanolic extracts of Allium sativum against some selected microorganisms

\begin{tabular}{ccccc}
\hline Organisms & \multicolumn{4}{c}{ Zone of inhibition $(\mathrm{mm})$ Concentration } \\
\cline { 2 - 5 } & Control & $10 \mathrm{mg} / \mathrm{ml}$ & $20 \mathrm{mg} / \mathrm{ml}$ & $30 \mathrm{mg} / \mathrm{ml}$ \\
\hline Staphylococcus aureus & $0.00 \pm 0.00^{\mathrm{a}}$ & $2.50 \pm 0.12^{\mathrm{b}}$ & $3.00 \pm 0.10^{\mathrm{c}}$ & $4.50 \pm 0.10^{\mathrm{d}}$ \\
Klebsiellapneumoniae & $0.00 \pm 0.00^{\mathrm{a}}$ & $5.50 \pm 0.12^{\mathrm{b}}$ & $7.00 \pm 0.15^{\mathrm{c}}$ & $9.50 \pm 0.21^{\mathrm{d}}$ \\
Escherichia coli & $0.00 \pm 0.00^{\mathrm{a}}$ & $7.00 \pm 0.21^{\mathrm{b}}$ & $9.50 \pm 0.10^{\mathrm{c}}$ & $12.50 \pm 0.20^{\mathrm{d}}$ \\
Bacillus subtilis & $0.00 \pm 0.00^{\mathrm{a}}$ & $2.50 \pm 0.21^{\mathrm{b}}$ & $3.50 \pm 0.10^{\mathrm{c}}$ & $5.00 \pm 0.15^{\mathrm{d}}$ \\
\hline Pseudomonas aeruginosa & $0.00 \pm 0.00^{\mathrm{a}}$ & $6.50 \pm 0.21^{\mathrm{b}}$ & $8.50 \pm 0.15^{\mathrm{c}}$ & $11.00 \pm 0.20^{\mathrm{d}}$ \\
\hline
\end{tabular}

Key: Each value is a mean of three determinations \pm standard deviation. Different superscripts across the table are significantly different $(p<0.05)$

Tab. 4. The bacteriostatic effects of aqueous and ethanolic extracts of Allium sativum

\begin{tabular}{|c|c|c|c|c|c|c|}
\hline \multirow{3}{*}{ Organisms } & \multicolumn{6}{|c|}{$\begin{array}{l}\text { Concentrations of } \\
\text { extracts }(\mathrm{mg} / \mathrm{ml})\end{array}$} \\
\hline & \multicolumn{3}{|c|}{$\begin{array}{c}\text { Aqueous } \\
\text { extracts } \\
\end{array}$} & \multicolumn{3}{|c|}{$\begin{array}{c}\text { Ethanolic } \\
\text { extracts }\end{array}$} \\
\hline & 10 & 20 & 30 & 10 & 20 & 30 \\
\hline Staphylococcus aureus & - & - & - & - & - & + \\
\hline Klebsiella pneumoniae & - & - & + & - & - & + \\
\hline Escherichia coli & - & + & + & - & + & + \\
\hline Bacillus subtilis & - & - & - & - & - & + \\
\hline Pseudomonas aeruginosa & - & - & + & - & - & + \\
\hline
\end{tabular}

Key: $+=$ Growth inhibition by the extracts. - = No growth inhibition by the extracts.
Tab. 5. The bactericidal effects of aqueous and ethanolic extracts of Allium sativum

\begin{tabular}{cccccccc}
\hline & \multicolumn{5}{c}{$\begin{array}{c}\text { Concentrations of } \\
\text { Oxtracts }(\mathrm{mg} / \mathrm{ml})\end{array}$} \\
\cline { 2 - 7 } & \multicolumn{3}{c}{$\begin{array}{c}\text { Aqueous } \\
\text { Extracts }\end{array}$} & \multicolumn{3}{c}{$\begin{array}{c}\text { Exhanolic } \\
\text { Extracts }\end{array}$} \\
\cline { 2 - 7 } & 10 & 20 & 30 & 10 & 20 & 30 \\
\hline Staphylococcus aureus & - & - & - & - & - & - \\
\hline Klebsiella pneumoniae & - & - & - & - & - & - \\
Escherichia coli & - & - & - & - & - & + \\
Bacillus subtilis & - & - & - & - & - & - \\
Pseudomonas aeruginosa & - & - & - & - & - & + \\
\hline
\end{tabular}

Key: + = Growth inhibition of the organism by the extracts. - = No growth inhibition of the organism by the extracts

Tab. 6. Comparison of the antimicrobial efficacy of the ethanolic extracts of Allium sativum with standard antibiotics

\begin{tabular}{ccccc}
\hline Test Organisms & \multicolumn{4}{c}{ Zone of inhibition $(\mathrm{mm})$} \\
\hline Staphylococcus aureus & Allium sativum & Chloramphenicol & Ampicillin & Cotrimoxazole \\
\hline Klebsiella pneumoniae & 4.50 & 19.50 & 6.00 & 0.00 \\
Escherichia coli & 9.50 & 0.00 & 18.00 & 26.50 \\
Bacillus subtilis & 12.50 & 23.00 & 19.50 & 18.00 \\
Pseudomonas aeruginosa & 5.00 & 17.50 & 6.00 & 0.00 \\
\hline
\end{tabular}

Key: ${ }^{*}=$ Concentrations of extract and antibiotics used $=30 \mathrm{mg} / \mathrm{ml}$.

Also the bactericidal effects of ethanolic extracts were shown at $30 \mathrm{mg} / \mathrm{ml}$ for Escherichia coli and Pseudomonas aeruginosa but no bactericidal effects was shown on Klebsiella pneumoniae, Bacillus subtilis and Staphylococcus aureus.

The comparison of the antibacterial efficacy of the ethanolic extracts with standard antibiotics is presented in Tab. 6, the antibiotics tested were more effective than the extracts in most cases.

\section{Discussion}

The Phytochemical screening of ethanolic extract of Allium sativum shows that it contains alkaloids, saponins, tannins ( Tab. 1). Many plants that are rich in phenolics compound have been reported to exhibit antibacterial effects.

Okerulu and Ani (2001) reported that extracts of the seeds of Tetracarpidium canophorum contains tannins and flavonoids and were found to have inhibitory effects on the growth of Streptococcus viridans, Bacillus spp. and Staphylococcus aureus. Therefore the presence of tannins in the ethanolic extract of Allium sativum could partly be accountable for the observed antibacterial effects in this work. They exhibited their antibacterial action through effects on membrane permeability and inhibition of membrane bound enzymes such as the ATPase and Phospholipase A2 (Hausteen, 1983). The result presented above indicates that the extract of Allium sativum had antimicrobial properties, thus justifying their traditional use as a medicinal plant.

The present study showed that the aqueous and ethanolic extracts of Allium sativum exhibited antibacterial activity against some medically important bacteria. The extract showed a differential activity against the test organisms. The bioactive extraction potential of the solvents was determined in terms of the extent to which the aqueous or ethanolic extract inhibited the growth of all the test organisms at a concentration of $30 \mathrm{mg} / \mathrm{ml}$. In this study 
water was observed to be a poor extractant while ethanol seemed to be better, as its extracts in most cases possessed the widest spectra of activities and was more effective on the test bacteria than the aqueous extract. This observation suggests that the active substances for Allium sativum are more soluble in ethanol than in water. This is in harmony with the work of Ibekwe et al. (2000).

The work of Brain and Turner (1995) indicated that the efficacy of an extraction procedure depends upon the accessibility of the constituent to the solvents. The result is also in accord with the report of Majekodunmi et al. (1996) and Martinez et al. (1996) that a higher activity of extrac Tab. natural products was obtained in ethanol compared with aqueous extracts. Ethanol extract of $\mathrm{Al}$ lium sativum inhibited the growth of all the test organism while aqueous extracts was effective only on Escherichia coli, Pseudomonas aeruginosa and Klebsiella pneumonia (Tab. 2). The increase in the antimicrobial effectiveness observed with increase in concentration of the extract (Tab. 2 and 3) is in agreement with the work of Boakye Yiedom (1979) who reported that higher concentration of anti-bacterial substances showed appreciable growth inhibition of bacteria.

The extracts with low activity against an organism had high MIC while the extract with high activity gave a low MIC (Emeruwa, 1982; El-Faraley et al., 1983). Investigation into the antibacterial effectiveness of ethanolic extracts of Allium sativum revealed that the sample have lower activity compared with those of the conventional antibiotics ( Tab. 6).

It has been shown in this work that the use of extracts of Allium sativum for curing cholera, dysentery, and urinary tract infections is justified by the effectiveness of its extract on Escherichia coli, Pseudomonas aeruginosa and Klebsiella pneumoniae which are known pathogens especially in immunocompromised persons. Some researchers have described the antibacterial activity of garlic extract against microorganisms. Bulbs belonging to the Allium genus had the most antibacterial activity against Streptococcus mutans (Ohara et al., 2008) and against Streptococcus agalactiae (Alsaid et al., 2010). Garlic has antimicrobial activity against Escherichia coli, Salmonella typhi, Shigella flexineri, Proteus mirabilis (Shobana et al., 2009); Streptococcus olaris, Streptococcus mitis, Staphylococcus aureus (Silva and Fernandes, 2010; Daka, 2011); and Vibrio parahaemolyticus, Escherichia coli and Staphylococcus aureus (Vuddhakul et al, 2007). Studies have shown some bacteria to be resistant towards garlic extract and these include Escherichia coli and Staphylococcus aureus (Esimone et al., 2010). This is an indication that when further subjected to in vivo trials after isolation and characterization of the active components; as well as elucidation of the structure of such components, it can be used to treat diseases such as typhoid fever, urinary tract infections (UTI), pneumonia and a host of other. Efforts should include the determination of their relative toxicity to patients, suitability and possible contra-indication in oral use after they could be incorporated into drugs for the treatment of diseases.

\section{Conclusions}

The use of the extracts of Allium sativum for curing cholera, dysentery and urinary tract infections is justified by the effectiveness of its extract on Escherichia coli, Pseudomonas aeruginosa and Klebsiella pneumonia. Nevertheless, further work is still required to purify the active ingredients of Allium sativum which have potential for combating human disease. Clinical evaluation of spices in in vivo experiments is required to be carried out for low cost treatment with few side effects. In addition toxicological studies need to be evaluated.

\section{Acknowledgement}

We are thankful to the Management of University of Ilorin Teaching Hospital for providing the pure bacterial isolates used in this research work.

\section{References}

Alsaid M, Daud H, Bejo SK, Abuseliana A (2010). Antibacterial activities of some culinary spice extracts against Streptococcus agalactiac and its prophylactic used to prevent streptococcal infection in red hybrid Tilapia (oreochromis sp.). World J Fish Marine Sci 2:(6)532-538.

Baker FJ, Breach MR (1980). Medicinal Microbiology Techniques. Butterworth and Co-publisher Limited, London, 348-349 p.

Balch PA (2000). Prescription for Nutritional Healing, $3^{\text {rd }}$ Edition. Avery New York, 112-140 p.

Barry AL, Thornberry C (1991). Clinical Microbiology. $5^{\text {th }}$ Edition. American Society for Microbiology, Washington, 1117-1125 p.

Bauer AW, Kirby WMM, Sherries SC, Turk M (1966). Antibiotic susceptibility testing by a standard single disc method. Am J Clinical Pathol 36:492-496.

Boakye-Yiadom K (1979). Antimicrobial activities of aqueous extract of Cryptolepsis anguinolenta. Lindl. Schlechter Quarterly J 17(2):78-80.

Brain KR, Turner TD (1975). Basic Medical Microbiology. $4^{\text {th }}$ Ed. Little Brown, Boston, 402-511 p.

Daka D (2011). Antibacterial effect of garlic (Allium sativum) on Staphylococcus aureus: an in vitro study. Afr J Biotechnol 10:666-669.

Durairaj S, Srinivasan S, Lakshmanaperumalsamy P (2009). In vitro antibacterial activity and stability of garlic extract at different $\mathrm{pH}$ and temperature. Electronic J Biol 5(1):5-10.

El-Faraley YS, Cheatham SF, Breelove RL (1983). Antimicrobial Neolignans of Sassafras randaiense root. Lloydia 46(4):493497.

Emeruwa AC (1982). Antibacterial substance from Carica pa- 
188

paya fruit extracts. J Nat Product 45(2):123-127.

Esimone CO, Okoye FBC, Odimegwu DC, Nworu CS, Oleghe PO, Ejogha PW (2010). In vitro antimicrobial evaluation of lozenges containing extract of garlic and ginger. Internat J Health Res 3:105-110.

Gull IM, Saeed M, Shaukat H, Aslam SM, Samra ZQ, Athar AM (2012). Inhibitory effect of Allium sativum and Zingiber officinale extracts on clinically important drug resistant pathogenic bacteria. Ann Clin Microbiol Antimicrob 11:8.

Hausteen B (1983). Plant flavonoids in biology and medicines. Biochem Pharmacol 32(7):1141-1148.

Harborne JB (1973). A Guide to Modern Techniques of Plant Analysis. Chapman and Hall, London, 279 p.

Ibekwe VI, Ubochi KC, Anyanwu BN (2000). Prevalence of Penicillin Resistance in organisms that cause sexually transmitted diseases in Port Harcourt, Nigeria. Int J Environ Health Res 10:251-255.

Ilori MO, Sheiteola A, Omonigbehin EA, Adeneye AA (1996). Antidiarrhoeal activities of Ocimium gratissimium (Lamiaceae). J Diarrhoea Dis Res 14:54-58.

Iwalokun BA, Ogunledun A, Ogbolu DO, Bamiro SB, JimiOmojola J (2004). In-vitro anti-microbial properties of aqueous garlic extract against multidrug-resistant bacteria and Candida species from Nigeria. J Med Food 7:327-333.

Jabar MA, Al-Mossawi A (2007). Susceptibility of some multiple resistant bacterial to garlic extract. Afr J Biotechnol 6:771-776.

Karuppiah P, Rajaram S (2012). Antibacterial effect of Allium sativum cloves and Zingiber officinale rhizomes against clinical pathogens. Asian Pacific J Tropl Biomed 2:597-601.

Leong J, Yang CC (1981).Mode of antibiotics action of 4-hydroxy-3-nitrosobenzaldehyde from Streptomyces viridans. Antimicrobial Agents Chemotherapy 20(4):558-562.
Majekodunmi OF, Zany L, Ohayaga IE., ShileMclanghin JL (1996). Selective cytotoxic diterpene from Euphorbia poisonic. J Med Chem 39(4):1005-1008.

Mitscher LA, Pingleu R, Bathala MS (1972). Antimicrobial agents from higher plants. Lloydia 35(2):157-166.

Odebiyi A, Sofowora AE (1978). Antimicrobial alkaloids from a Nigeria chewing stick Fagara zanthozyboides. Plantamedica 40:204-207.

Ohara A, Saito F, Matsuhisa T (2008). Screening of antibacterial activities of edible plants against Streptococcus mutans. Food Sci Technol Res 14:190-193.

Okerulu JO, Ani CJ (2001). The phytochemical analysis and antibacterial screening of extracts of Tetracarpidium cornophorum. J Chem Soc Nigeria 1:53-55.

Prashanth K, Neelam S, Harish P, Rajani M (2006). Search for antibacterial and antifungal agents from selected Indian medicinal plants. J Ethnopharmacol 107:182-188.

Shobana S, Vidhya VG, Ramya M (2009). Antibacterial activity of garlic varieties (ophioscordon and sativum) on enteric pathogens. Curr Res J Biol Sci 1:123-126.

Silva NCC, Fernandes-Junior A (2010). Biological properties of medicinal plants: A review of their antimicrobial activity. The J Venomous Animals Toxins Including Trop Dis 16:402-413.

Ung-Kyu C, Ok-Hwan L, Seong-Il L, Young-Chan K (2010). Optimization of antibacterial activity of Perilla frutescens var. acuta leaf against Pseudomonas aeruginosa using the evolutionary operation-factorial design technique. Int J Mol Sci 11(10):3922-3932.

Vuddhakul V, Bhoopong P, Hayeebilan F, Sabhadhirasakul S (2007). Inhibitory activity of Thai condiments on pandemic strain of Vibrio parahaemolyticus. Food Microbiol 24:413418 . 